\title{
Sexual and Asexual Propagation of Teucrium brevifolium
}

\author{
Anastasia AKOUMIANAKI - IOANNIDOU*, Aikaterini GERASIMIDOU, Alexandra SALTA \\ Laboratory of Floriculture and Landscape Architecture, Department of Crop Science, School of \\ Agriculture, Engineering and Environmental Sciences, Agricultural University of Athens, Iera Odos 75, \\ 11855 Athens, Greece \\ *corresponding author: akouman@aua.gr
}

Bulletin UASVM Horticulture 75(2) / 2018

Print ISSN 1843-5262, Electronic ISSN 1843-536X

DOI:10.15835/buasvmcn-hort: 2018.0011

\begin{abstract}
The propagation with seeds and stem cuttings of Teucrium brevifolium were investigated in order to facilitate the use of the species in floricultural practice and as a medicinal plant. The seeds after they subjected to different types of treatments (dipping in $\mathrm{H}_{2} \mathrm{SO}_{4}$ for $15 \mathrm{~min}$ or in $\mathrm{H}_{2} \mathrm{SO}_{4}$ for $15 \mathrm{~min}$ and $\mathrm{GA}_{3} 1000 \mathrm{mg} \mathrm{l}^{-1}$ for $10 \mathrm{~min}, 24$ or $48 \mathrm{~h}$ and untreated) cultured for germination in vitro at $5,10,15,20,25$, and $30^{\circ} \mathrm{C}$. The cuttings were planted in a peat/perlite mixture $1: 1 \mathrm{v} / \mathrm{v}$ in plastic square plug trays in order to study the rooting percentage. Seed germination was very low (2\%) at temperatures of $15-25{ }^{\circ} \mathrm{C}$, while chemical treatment with the concentrated $\mathrm{H}_{2} \mathrm{SO}_{4}$ for 15 min, increased germination to $8-10 \%$ at the same temperatures. Asexual propagation of the species resulted in a $52.5-61.5 \%$ rooting percentage, in all seasons except winter. Treatment with IBA $2000 \mathrm{mg} \mathrm{l}^{-1}$ increaseds rooting percentage.
\end{abstract}

Keywords: IBA rooting hormone, medicinal plant, seed germination, stem cuttings, wild plant

\section{Introduction}

Teucrium brevifolium (Lamiaceae) is an evergreen, small shrub, up to $60 \mathrm{~cm}$ height with many branches and rounded shape on the soil surface (D1). The leaves are grey-green and the flowers, located at the nodes (single or in raceme), are small and white-purple with purple ribs. $T$. brevifolium blooms from winter (December) to the early springtime, which consists a critical season for the bees, as their natural food is limited during this time of the year (D2). The species grows in calcareous rocks, coastal and rocky areas of the central and southern Greece and in some islands of the western and southern Aegean as well. The wild plants grow in sunny and warm locations up to $400 \mathrm{~m}$ altitude (D3). This study investigates the propagation of this species, in order to examine its suitability for use as an ornamental plant in areas with adverse conditions, such as archaeological sites, surrounding areas, roof gardens and areas in need of redevelopment.

\section{Materials and Methods}

For the sexual propagation of this species, seeds were collected from wild plants in Milos island, and after they were stored for six months at a temperature of $21^{\circ} \mathrm{C}$ and dark, they were used for in vitro germination experiments. In the first experiment, the seeds were disinfected with chloride solution (15\% for $10 \mathrm{~min})$ and then subjected to different types of treatments except the control as follow: chemical scarification: chemical scarification with concentrated $\mathrm{H}_{2} \mathrm{SO}_{4}$ for $15 \mathrm{~min}$, chemical scarification with concentrated $\mathrm{H}_{2} \mathrm{SO}_{4}$ for 15 min followed by dipping in $\mathrm{GA}_{3}$ $1000 \mathrm{mg} \mathrm{l}^{-1}$ for $10 \mathrm{~min}$ and no treatment (control seeds). Consequently, the seeds were cultured in vitro for germination in Petri dishes with solid (8 
Table 1. Seed germination of T. brevifolium at $10,15,20$ and $25{ }^{\circ} \mathrm{C}$ undergoing different treatments in concentrated $\mathrm{H}_{2} \mathrm{SO}_{4}$ for 15 min and followed by dipping in $\mathrm{GA}_{3} 1000 \mathrm{mg} \mathrm{l}^{-1}$ for 10 min

\begin{tabular}{|c|c|c|}
\hline Treatment & $\begin{array}{c}\text { Temperature } \\
\left({ }^{\circ} \mathrm{C}\right)\end{array}$ & $\begin{array}{c}\text { Germination (\%) } \\
\pm \mathrm{SE}\end{array}$ \\
\hline \multirow[t]{4}{*}{ Control } & 10 & $0.00 \pm 0.00$ \\
\hline & 15 & $0.00 \pm 0.00$ \\
\hline & 20 & $2.00 \pm 0,83$ \\
\hline & 25 & $0.00 \pm 0.00$ \\
\hline \multirow[t]{4}{*}{ c. $\mathrm{H}_{2} \mathrm{SO} 4$} & 10 & $4.00 \pm 2,44$ \\
\hline & 15 & $8.00 \pm 3,39$ \\
\hline & 20 & $10.00 \pm 4.47$ \\
\hline & 25 & $8.00 \pm 4.89$ \\
\hline \multirow[t]{4}{*}{ c. $\mathrm{H}_{2} \mathrm{SO} 4 / \mathrm{GA}_{3}$} & 10 & $0.00 \pm 0.00$ \\
\hline & 15 & $8.00 \pm 3.74$ \\
\hline & 20 & $8.00 \pm 2.00$ \\
\hline & 25 & $0.00 \pm 0.00$ \\
\hline \multicolumn{2}{|c|}{$F_{\text {treat }}$} & NS \\
\hline \multicolumn{2}{|c|}{$F_{\text {temp }}$} & NS \\
\hline \multicolumn{2}{|c|}{$F_{\text {inter. }}$} & NS \\
\hline
\end{tabular}

$\mathrm{g} \mathrm{l}^{-1}$ agar) half-strength (1/2) Murashige and Skoog growth medium (MS) with $2 \%$ sucrose and $5,7 \mathrm{pH}$ at different temperatures $\left(10,15,20\right.$, and $\left.25^{\circ} \mathrm{C}\right)$, under 16 hours light and $37.5 \mu \mathrm{mol} \mathrm{m} \mathrm{m}^{-2} \mathrm{~s}^{-1}$ light intensity derived from fluorescent lamps. During the second experiment, the time of dipping seeds in $\mathrm{GA}_{3}$ was investigated; seeds received treatments as follow: dipping in concentrated $\mathrm{H}_{2} \mathrm{SO}_{4}$ for 15 min and dipping in concentrated $\mathrm{H}_{2} \mathrm{SO}_{4}$ for 15 min followed by dipping in $\mathrm{GA}_{3} 1000 \mathrm{mg} \mathrm{l}^{-1}$ for 24 and $48 \mathrm{~h}$. After the pretreatments, seeds were transfered for in vitro germination in Petri dishes at temperatures of $5,10,15,20,25$ and $30^{\circ} \mathrm{C}$. For each temperature, 5 repetitions ( 5 dishes) with 10 seeds per repetition $\left(5^{*} 10=50\right.$ seeds $)$ were used. Regarding the asexual propagation, cuttings measuring 8-10 cm long, deriving from the apical part of shoots, were harvested in April, July, October 2016 and February 2017, from mature wild plants of the species, located in Legrena area in Sounio Attica, corresponding to the four seasons. The cuttings, after dipping treatment in IBA rooting hormone ethanol-water solutions $(1: 1, \mathrm{v} / \mathrm{v})$ at concentrations of 1000, 2000 and $3000 \mathrm{mg} \mathrm{L}^{-1}$ for $1 \mathrm{~min}$, were placed for rooting in a peat-perlite substrate $(1: 1, \mathrm{v} / \mathrm{v})$ on a bench in the greenhouse outside of the misting system; irrigation was provided manually every three days for two months in order to calculate the rooting rates of the cuttings. 50 cuttings in 5 repetitions of 10 cuttings were used for each season and treatment. The experiments were conducted according to the completely randomized experimental design.

The data were analyzed by applying one and two-way ANOVA to check the diffidences between the means. In order to determine the statistically significant differences between the mean values, the Student $t$ test was used at the $5 \%$ level of significance. $(\mathrm{P}=0.05)$.

\section{Results and Discussion}

Germination percentage was very low (2\%) at temperatures of $15-25^{\circ} \mathrm{C}$ (Tab. 1) while chemical scarification with the concentrated $\mathrm{H}_{2} \mathrm{SO}_{4}$ for $15 \mathrm{~min}$, increased the germination percentage to $8-10 \%$ at the same temperatures (Table 1). Chemical pretreatment combined with dipping in $\mathrm{GA}_{3}$ for $10 \mathrm{~min}$, sustained germination at the same levels $(8 \%)$ at the same temperatures (Tab. 1), while longer dipping time in $\mathrm{GA}_{3}(24 \mathrm{~h})$ resulted 
Table 2. In vitro seed germination of $T$. brevifolium at 5, 10, 15, 20, 25 and $30^{\circ} \mathrm{C}$ as affected from dipping in concentrated $\mathrm{H}_{2} \mathrm{SO}_{4}$ for $15 \mathrm{~min}$ and followed by dipping in $\mathrm{GA}_{3} 1000 \mathrm{mg}$ $\mathrm{l}^{-1}$ for 24 and $48 \mathrm{~h}$

\begin{tabular}{|c|c|c|}
\hline Treatment & Temperature $\left({ }^{\circ} \mathrm{C}\right)$ & Germination (\%) $\pm \mathrm{SE}$ \\
\hline \multirow[t]{6}{*}{ Control } & 5 & $0.00 \pm 0,00$ \\
\hline & 10 & $0.00 \pm 0,00$ \\
\hline & 15 & $0.00 \pm 0,00$ \\
\hline & 20 & $0.00 \pm 0,00$ \\
\hline & 25 & $0.00 \pm 0,00$ \\
\hline & 30 & $0.00 \pm 0,00$ \\
\hline \multirow[t]{6}{*}{$\mathrm{H}_{2} \mathrm{SO}_{4} / \mathrm{GA}_{3} 24 \mathrm{~h}$} & 5 & $0.00 \pm 0,00$ \\
\hline & 10 & $16.00 \pm 2.44 \mathrm{a}$ \\
\hline & 15 & $14.00 \pm 7.48 \mathrm{ab}$ \\
\hline & 20 & $18.00 \pm 3.74 \mathrm{a}$ \\
\hline & 25 & $16.00 \pm 6.78 \mathrm{a}$ \\
\hline & 30 & $2.00 \pm 0.54 b$ \\
\hline \multirow[t]{9}{*}{$\mathrm{H}_{2} \mathrm{SO}_{4} / \mathrm{GA}_{3} 48 \mathrm{~h}$} & 5 & $0.00 \pm 0,00$ \\
\hline & 10 & $6.00 \pm 2.44 \mathrm{ab}$ \\
\hline & 15 & $12.00 \pm 5.83 \mathrm{ab}$ \\
\hline & 20 & $0.00 \pm 0.00$ \\
\hline & 25 & $8.00 \pm 3.74 \mathrm{ab}$ \\
\hline & 30 & $2.00 \pm .94 \mathrm{~b}$ \\
\hline & & $* *$ \\
\hline & & $* *$ \\
\hline & & $*$ \\
\hline
\end{tabular}

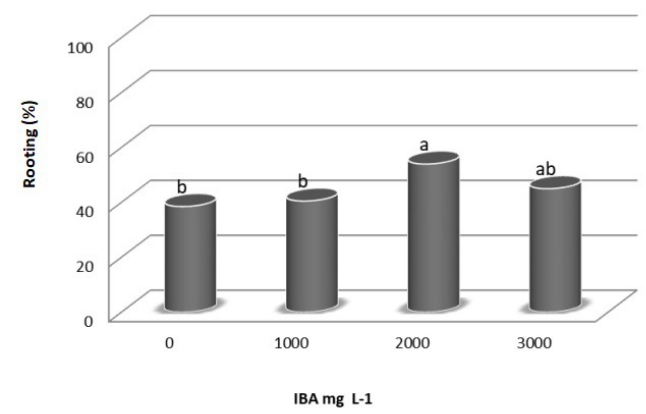

Figure 1. IBA concentration effect on rooting of $T$. brevifolium cuttings, collected in four different seasons

in a small increase of the germination rates, to 14$18 \%$ (Tab. 2). None of the seeds were germinated at the temperature of $5{ }^{\circ} \mathrm{C}$, while germination percentage was very low $(2 \%)$ at $30^{\circ} \mathrm{C}$ (Tab. 2). Similar germination rates of $T$. capitatum were also

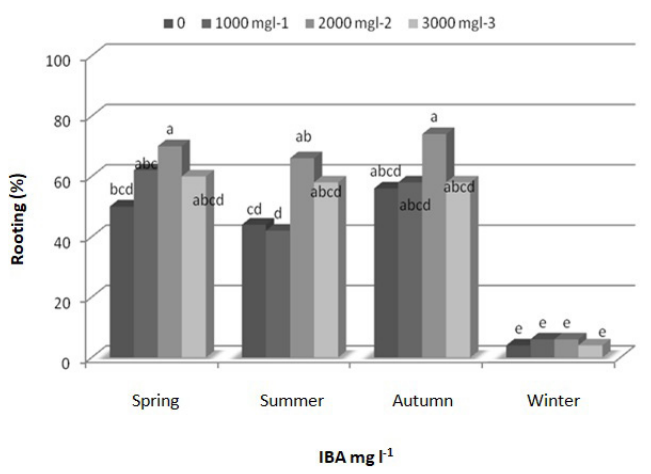

Figure 2. Effect of collection season and IBA concentration on rooting of $T$. brevifolium cuttings

found by Luna and Moreno (2009) and Papafotiou et al. (2013).

IBA rooting hormone significantly affected rooting; the most efficient IBA concentration was $2000 \mathrm{mg} \mathrm{l-1} \mathrm{(54 \% ),} \mathrm{but} \mathrm{no} \mathrm{significant} \mathrm{difference}$ 
was shown between 2000 and $3000 \mathrm{mg} \mathrm{l}-1$ (45\%) (Fig. 1). Season of harvesting also affected the rooting significantly; higher rooting rates were achieved for cuttings that were harvested in autumn (61.5\%) and spring (60.5\%) Based on the statical analyses no significant differences were shown in rooting percentage (capacity) between the cuttings harvested in autumn, spring and summer (52.5\%). Rooting rates for cuttings that were harvested in winter were very low (3.5\%) (Fig. 2). Highest rooting rates were observed from cuttings collected in spring and autumn and received treatment with IBA 2000 mg l-1 (70\% and 74\% respectively). According to Papafotiou et al. (2013), cuttings of T. capitatum that were collected in spring and autumn and received treatments with IBA 1000, 2000 or 3000 $\mathrm{mg} \mathrm{l}^{-1}$ as well, resulted higher rooting rates in comparison with cuttings that did not receive any treatment (control) and IBA concentration did not significantly affect the results.

\section{Conclusions}

Sexual propagation of T. brevifolium is promoted by chemical scarification of the seeds at temperatures of $15-20^{\circ} \mathrm{C}$, with low germination percentage (8-10\%). Chemical scarification follo- wed by dipping in $\mathrm{GA}_{3}$ for $24 \mathrm{~h}$, increased germination percentage to $14-18 \%$ at the same temperatures. Asexual propagation of the species by stem cuttings that were harvested in all seasons except winter, resulted in a 52.5-61.5\% rooting rate. Treatment with IBA $2000 \mathrm{mg} \mathrm{l}^{-1}$ increased rooting percentage.

\section{References}

1. Luna B and Moreno JM (2009). Light and nitrate effects on seed germination of Mediterranean plant species of several functional groups. Plant Ecol 203:123-135.

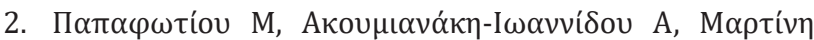

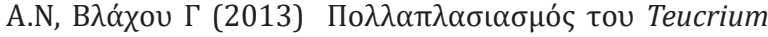

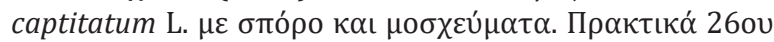

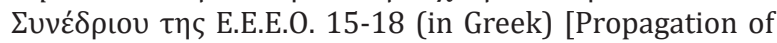
teucrium capitatum by seed and stem cuttings].

3. D1 Wild Flowers of Greece. URL.

4. http://www.greekflora.gr/el/flowers/1242/Teucriumbrevifolium

5. D2 Flora cytherea (A record of wild plants in Cethera island). URL

6. http://floracytherea.blogspot.gr/2011/01/blog-post_22. html

7. D3 Manual for the propagation of selected Mediterranean native plant species. URL

8. https://ahim.files.wordpress.com/2015/12/manualpropagation-mediterranean-plant species-2015.pdf3 